Teknokultura. Revista de Cultura Digital y Movimientos Sociales

ISSNe: $1549-2230$

http://dx.doi.org/10.5209/TEKN.64857

\title{
Yucky gets yummy: how speculative fiction creates society
}

\author{
PJ. Manney ${ }^{1}$
}

Recibido: 23 de junio 2019 / Aceptado: 9 de octubre 2019

\begin{abstract}
Human biology creates empathy through storytelling and emulation. Throughout history, humans have honed their capacity to understand optimum storytelling and relate to others in new ways. The bioethical concepts of Leon Kass's Wisdom of Repugnance and Arthur Caplan's Yuck Factor attempt to describe, and in Kass's case even support, society's abhorrence of that which is strange, against God or nature, or simply the "other". However, speculative fiction has been assessing the "other" for as long as we've told speculative stories. The last thousand years of social liberalization and technological progress in Western civilization can be linked to these stories through feedback loops of storytelling, technological inspiration and acceptance, and social change by growing the audience's empathy for these speculative characters. Selecting highlights of speculative fiction as far back as the Bible and as recently as the latest movie blockbusters, society has grappled back and forth on whether monsters, superhumans, aliens, and the "other" are considered villainous, frightening and yucky, or heroic, aspirational and yummy. The larger historical arc of speculative fiction, technological acceptance and history demonstrates the clear shift from yucky to yummy. Works include The Bible, Talmud, stories of alchemists and the Brazen Head, Paradise Lost, Frankenstein, Dr. Jekyll and Mr. Hyde, The Wonderful Wizard of Oz, gothic horror films of Germany and the U.S., Superman and the Golden Age of comics, and recent blockbusters, among others.
\end{abstract}

Keywords: empathy; fantasy; monsters; "other"; science fiction; superheroes.

\section{[es] Lo repulsivo torna en delicioso: cómo la ficción especulativa crea sociedad}

Resumen. La biología humana crea empatía mediante la narración y la imitación. A través de la historia, los humanos han perfeccionado su capacidad para comprender la narración óptima y relacionarse con otros de nuevas maneras. Los conceptos bioéticos de Wisdom of Repugnance de Leon Kass y Yuck Factor de Arthur Caplan son un intento de describir, y en el caso de Kass, hasta apoyar la aversión de la sociedad a lo que es extraño, contra Dios o la naturaleza, o sencillamente, "lo otro"'. Sin embargo, la ficción especulativa ha estado evaluando "lo otro" desde que hemos contado historias especulativas. Los últimos mil años de liberalización social y progreso tecnológico en la civilización occidental pueden vincularse a estas historias a través de los bucles de reacción a la narración, la inspiración tecnológica y la aceptación, y el cambio social al aumentar la empatía de la audiencia por estos personajes teóricos. Seleccionando los puntos importantes de la ficción especulativa desde los tiempos de la Biblia y tan recientemente como las últimas películas taquilleras de largometraje, la sociedad ha luchado con la idea de si los monstruos, los superhombres, los alienígenas, y "los otros" se pueden considerar abominables, terroríficos o asquerosos, o heroicos, inspiradores y sabrosos. El gran arco de ficción especulativa, aceptación tecnológica e historia demuestra un claro cambio de asqueroso a sabroso. Las obras incluyen la Biblia, el Talmud, las historias de alquimistas, y The Brazen Head, Paraíso Perdido, Frankenstein, El extraño caso del doctor Jekyll y el señor Hyde, El mago de Oz, películas góticas de horror alemanas y estadounidenses, Superman y la era dorada de las historietas, tebeos o cómics, y las recientes películas taquilleras, entre otras.

1 Wesleyan University (Connecticut)

E-mail: pjmanney@gmail.com 
Palabras clave: ciencia ficción; empatía; fantasía; monstruos; superhéroes.

Summary. 1. Introduction, 2. Empathy is social and biological, 3. Two things to remember, 4. Speculative fiction as an empathy engine, 5. Yucky and Yummy pre 20th Century, 6. The 19th century: transition from creator to created, 7. The 20th century changes everything, 8 . And heeeeere's Yummy!, 9. So Why is this important?

Cómocitar: Manney,PJ.(2019). Yucky getsyummy:how speculativefiction creates society. Teknokultura. Revista de Cultura Digital y Movimientos Sociales, 16(2), 243-254.

\section{Introduction ${ }^{2}$}

In 1977, I was a 12-year-old science fiction and fantasy fan and saw a movie that changed me forever. The movie was in an old-fashioned sub-genre of speculative fiction called "science fantasy," meaning there are futuristic or technological elements, but there's also magic, monarchies and monsters. Of course, it was Star Wars. And there was a character I'd never seen before in a movie. While she was technically a princess that needed saving, she kicked ass and took names with the best of them.

Princess Leia represented the beginning for many women of my generation of a flowering of female protagonists, like Ripley in Alien, Sarah Connor in Terminator, and Eleanor Arroway in Contact. These women changed how young women like us viewed our place in the world and said we could save the universe, regardless of how it needed saving. They made me realize how much more was possible.

Star Wars and these other films weren't the only speculative fiction stories to change how a group of people saw themselves and their place in the world. Fiction has been doing that for millennia. Fiction is the act of taking a story character who is not you, and projecting you into their story, in which you experience the world through the protagonist's eyes, in their shoes. And often in the shoes of those society would call the "other" or those not usually represented as powerful examples of that society. In doing so, these stories expanded the definition of who belonged in a society.

While working in film and TV (again, I chose my professions because of Star Wars), I became fascinated by how stories changed not only our personal ethical perceptions, but also society's views of social structures, morality and ethics, economics and social class, race, colonization and immigration.

But to get there, I had a more fundamental question. How do stories do this?

\section{Empathy is social and biological}

Let's start at the beginning with the science behind story. Why do we need stories? Humans are a story-making species. We've relied on narratives for our species sur-

This text is been adapted from a keynote speech given at University of California Santa Cruz's Social Fiction Conference, February 24, 2018. This speech and ideas have also appeared in: "Empathy in the Time of Technology: How Storytelling is the Key to Empathy" 2008 (https://jetpress.org/v19/manney.htm), "Is Technology Destroying Empathy" (https://www.livescience.com/51392-will-tech-bring-humanity-together-or-tear-it-apart. html) and "Five Books About Human Enhancement" (https://www.tor.com/2015/06/12/five-books-about-human-enhancement/). 
vival long before the story cave paintings of Lascaux, before human speech, before we drew stories in the dirt with sticks and made sounds like our primate cousins. This is demonstrated in a variety of scientific disciplines.

In evolutionary biology, stories matter because from moment to moment, our brains confront the randomness of reality. Brains don't like randomness, because it's harder to survive if we think everything in our experience is unrelated. Pattern recognition is intelligence. And communicating those patterns are the first stories. Some events are unrelated and have no obvious causality, except that which we make up in our heads. But other events are related, and they're often the things that keep us alive. For instance, if I lived with my family group on the savannah, and I saw a lion stalking me, I'd remember stories about lions, and know I must climb a tree to avoid being get eaten. And when I survive that encounter, I come home and relate that story. With luck, my family group and I will live long enough to reproduce and pass on our DNA. Or maybe we learn the story of how to find food. Or how to keep peace in our tribe. We create the stories we think we've observed, we tell ourselves to remember to important lessons, and we tell each other.

Physiologically, our bodies respond by triaging and balancing hormones. We produce cortisol in response to stress and excitement; that is part of the adrenaline rush, tenseness, dry mouth, knots in your stomach and desire to be close for protection in horror or thrillers. Oxytocin is the yin to cortisol's yang; it is why we experience the warm, fuzzy, touchy-feely response from a romantic comedy or romance. Date movies work for a reason.

From a neuroendocrinological standpoint, Dr. Paul Zak of Claremont Graduate University found that oxytocin, the "love" hormone, is produced when we personally experience an emotional event, or read or watch a story of that emotional experience; and experience empathy.

The neuroscience behind this is complex, and scientists are still working on the big picture of the mechanisms involved. Back in the 1990s, Italian scientists at the University of Parma including Giacomo Rizzolatti, Giuseppe Di Pellegrino, Luciano Fadiga, Leonardo Fogassi, and Vittorio Gallese, discovered macaque monkeys activated the same parts of their brains both in the act of doing something, as well as the observation of the same act. Scientists called the activated areas in the observing monkeys "mirror neurons".

By the mid-2000s, scientists and storytellers like myself started looking at the importance of stories and empathy creation in the brain. Mirror neurons had recently been discussed in scientific journals and the causal, biological root of storytelling and empathy began to form. However, mirror neurons remain a semi-controversial subject because we don't know the whole story, and some early hypotheses and assumptions by scientists didn't pan out. But instead of thinking of mirror neurons as a noun, I believe it's more helpful to think of mirror neurons as a verb: they're neurons mirroring. As a noun, it sounds like that neuron has one job, when neurons can have several functions, including aiding in an interconnected system of emulation and empathy, which both involve imagining yourself as another. This mirroring also affects theory of mind (the understanding that you have different beliefs and desires than others), language, self-awareness, and potentially other areas.

DARPA (Defense Advanced Research Projects Agency) and a team led by storyteller and former Army officer Kendall Haven also researched how stories work in our brains. They wanted to know what stories radicalize people to the point they 
want to kill others. Radicalization is part of the anti-empathy effect, because stories can create empathy or anti-empathy.

Through experiments involving all the brain and body changes or measurements they could come up with, they realized what I said before: Because we don't like randomness, you create stories before you're even conscious.

DARPA and Haven call it the Neural Story Net, or the Make Sense Mandate. Humans will ignore, change, create, infer and misinterpret it if it doesn't make sense. YOUR brain makes the story. You always did.

Since DARPA likes quantitative approaches, Kendal Haven's group came up with a formula one could even call it a Unified Field Theory of story:

$$
\mathrm{IP}=\mathrm{RRE}(\mathrm{D}-\mathrm{D}
$$

Where IP = Influence Potential, RRE = Audience's Residual Resolution Emotion, $\mathrm{D}=$ score for the Identity Character, and $\mathrm{D}=$ score for the Foe Character.

Your tax dollars are going towards a unified theory of effective storytelling to protect us from our political enemies. It's a delightful thought. If only.

\section{Two things to remember:}

- $\quad$ First: the size or context of your empathy is important. How we define ourselves as part of an in-group matters. The smaller the in-group, and the more empathy for that small in-group, the less empathy for the out-group "other". Think of "us" vs. "them" - the smaller the number of our "us," the worse we treat "them". Stories can be used to kill empathy. That's anti-empathy. We see this in sexist/racist/religious propaganda, nationalist fear mongering, and even in how groups like the military use video games. America's Army is used to recruit and desensitize their recruits to prepare them for war. The game teaches that your band of brothers and sisters are your empathy in-group. Anyone at the end of your gun is not. That is potentially a large number of people.

If you only empathize within the smallest version your self-identified group, you're not utilizing what humans are capable of concerning empathy. We can empathize beyond our tribe. We can empathize with humanity, possibly all living things, or at least show compassion. So fight the tribalism around us. It's an easy, lazy habit that can destroy society, not create positive futures.

- $\quad$ Second: Empathy is a muscle. It needs to get stronger and it needs to be stretched. It gets stronger consuming more stories from people unlike you. Research has shown that the more fiction one consumes, the more empathy one has. And empathy stretches to expand the context your empathy ingroup. Increase your empathy weights and reps. Use it or lose it.

Together, there is a complex brain/body reaction while we imagine or receive a story, and depending on the size of the empathy group and the repetition of empathy building, it will either produce empathy or anti-empathy each time we encounter a story. 


\section{Speculative fiction as an empathy engine}

My interest in empathy and speculative fiction began while reading Jane Smiley's work, 13 Ways of Looking at the Novel, where she explores the novel as an empathy engine. It's not only novels that can perform this function; it's any storytelling technique, although novels may do it better than other media, because we utilize our imaginations, following well-traveled neural pathways to construct our mental worlds.

Smiley believes the great subjects of novels - and I would argue, any narrative about individuals - is "Who am I? Are you like me? Are you different than me?" The most affecting subjects are often those whom society has deemed "the other" - alien to the social hierarchy's establishment of the time - and they often possess easily understood identities.

Grapes of Wrath said, "I am poor". Uncle Tom's Cabin said, "I am a slave". The Awakening said, "I am female. Oliver Twist said, "I am an orphan". Brokeback Mountain said, "I am gay". And I have an inner life you don't know about - until you know my story. Smiley convincingly argues that the last thousand years of social liberalization can be traced to consuming stories like these.

So where did YUCKY come from?

In 1994, bioethicist Arthur Caplan referred to the instinctive negative response to a new technology, calling it the Yuck Factor. Descriptive of 'technophobic sentiments' against new technology, this was not a recommended prohibition. However, in 1997, conservative bioethicist Leon Kass expanded the idea and called it "the wisdom of repugnance", meaning we should rely on an intuitive response to decide an ethical issue. Of course, when confronted with polluted water, rotten meat, or diseased bodies, it made sense. The physically disgusting thing in front of us might kill us. But this philosophy is not true when it comes to concepts or things that are strange or different. You might feel a sense of repugnance because you are afraid of something or someone unfamiliar. But is that feeling accurate? We might think a new concept is negative simply because it's alien to our experience. But is it?

Of course, it isn't. The fact that you haven't experienced or can't imagine something doesn't mean it's wrong.

Kass originally used this yuck factor argument against cloning, but the same arguments had been used against previous medical technologies like in-vitro fertilization, pain relief during childbirth, heart surgery, eyeglasses, prosthetics, germ theory, and cellular agriculture. And the objections have the same script: It's against God's will. It's unnatural. It's against the natural order of things. I just can't imagine it, so it must be bad.

But as we can see from the past, we usually overcame our reservations and adopted the technological solution. Often the solution was found in and inspired by speculative fiction. Fundamental technology is morally neutral and every one can be used for positive or negative purposes. Cloning by itself is not yucky and therefore, bad. Using it for inhumane and destructive purposes is bad. But there are scenarios in which cloning could be good. For instance, the cloning of individual organs. Or the cloning of livestock, which is now acceptable. There is the cloning of animal proteins to make lab grown meat, which is cruelty-free.

Therefore, applying the Yuck Factor to technological concepts isn't necessarily true. History, experience, intent, and, of course, storytelling changes how we see what we once thought of as yucky become yummy. 
This is where speculative fiction comes in as the fictional space we think about these new possibilities, and new ethical issues, playing different scenarios to different endings. And where we employ our empathy to understand new futures. So let's see how that played out in stories both yucky and yummy through history, through an arc of ever increasing liberalization and empathy.

\section{Yucky and yummy pre 20th century}

Before the $20^{\text {th }}$ Century in western culture, a god with superhuman attributes usually brought good news, and was therefore, yummy - or at least most religions said so. However, a human playing God, or a monster, or superhuman behaved strangely, was perceived as dangerous and bad news, and therefore yucky. However, early positive examples of superhumans, monsters, and playing God grew as the centuries went on and society liberalized. The biggest shift, as we'll see, happened in the $20^{\text {th }}$ Century.

Pre- $20^{\text {th }}$ Century's speculative fiction protagonists began the trend. The conflict between yucky and yummy started early.

In Ancient Greece, stories and dramas about Prometheus couldn't agree on the yucky or yummy angle. Hesiod's Prometheus caused humankind's ills because he disobeyed and was yucky. Aeschylus' Prometheus brought humankind's gifts, and therefore yummy. However, regardless of the ethical spin, Prometheus - and humankind - suffer the Greek gods' wrath, because they try to do something against the gods' will.

In the Talmud, the ancient code of Jewish law, God made Adam of clay, then gave him a soul which imbued him with humanity. Because the protagonist Yahweh did the creating, Adam was yummy.

According to the New Testament, God created his son Jesus as part human, part divine. Jesus performs superhuman feats through his father's power and achieves immortality through resurrection. Within the story of Jesus, one could argue that while the readers are encouraged to see him as yummy, his enemies are afraid of his God-given superpowers and see him as yucky.

However, Adam and Jesus are only yummy protagonists because the first and biggest protagonist of the Bible - Yahweh/God - allows them to be. Both Adam and Jesus are character models on which many later speculative fiction protagonists would be based. Later allusions to these and other religious figures are used as a shortcut to empathy. Through repetitive religious storytelling, humans have well-established neural pathways for stories like them, so it pricks some of our strongest cultural programming whether we are believers or not. Stories as diverse as Superman, The Matrix, Battlestar Galactica, ET: The Extraterrestrial, among countless others, demonstrate the religious allegory path to quick empathy.

In Jewish medieval mythology, Golems are made of clay like Adam, but they're superhuman monsters created to protect Jews from attack. The Rabbi of Prague created the best-known golem to protect the Jewish Ghetto. This golem possessed super strength and loyalty, but was mute, since speech revealed human personality and intelligence, implying the creature had a soul and only God created souled creatures. Even hobbled, the golem could be dangerous and frightening, because the unsouled might wreak havoc if not properly managed. The Golem served a protective function for the Rabbi and his congregation, even though he might be a dangerous monster in anyone else's hands. 
The Middle Ages had a host of stories revolving around alchemists pursuing the philosopher's stone as a key to immortality and creating the "Brazen Head," a brass android head able to answer any question. In speculative fiction terms, it was an artificially intelligent android. The fact that the head's creation was attributed to superstar scientist/theologian/alchemists such as Pope Sylvester II, Robert Grosseteste, Roger Bacon and Saint Albertus Magnus indicated that not all devout Christians thought humans creating artificial life was wrong. Stories surrounding Saint Albertus Magnus also claimed he created a full-body android - indeed, he coined the word. But in most stories, Saint Thomas Aquinas decides the Brazen Head's existence is against God's will and smashes the android to smithereens, demonstrating Aquinas had the last word in superhuman and monster myths, as well as theology, for a few more centuries.

In 1667, John Milton's Paradise Lost brought Yahweh back, but he's not the protagonist. God might be the creator and Adam a hero, but it's the superhuman, monstrous, fallen angel Satan who is the antihero and protagonist by virtue of the readers' empathy. The story is the angelic war, Satan's fall from heaven, and Adam and Eve's expulsion from the Garden of Eden. However, Adam is such a whiny milquetoast, you couldn't care less if he and Eve piss off God and get kicked out of the Garden. Whereas Satan, even with weak theological arguments against his creator/parent, succeeds in garnering empathy through his anguish and anger from his abandonment by his creator. The Rolling Stones might say this created our sympathy for the devil.

\section{The 19th century: transition from creator to created}

And then, in 1818, comes the great watershed of speculative fiction, and the true beginning of the genre: Frankenstein. Victor Frankenstein, dubbed by Mary Shelley 'the modern Prometheus,' gives life, but fails the rest of the "Prometheus test", because the selfish, irresponsible, deadbeat dad doesn't bestow civilization's gifts upon his creature otherwise known as parenting your child. Instead, Victor runs away. The creature has to struggle to find those gifts for himself, with inevitably bad results. And why does Victor reject his creation/child? Because the creature is described as physically yucky. Both Victor and Captain Walton describe the creature in ghastly detail. Shelley definitely had something against men like her husband, his best friends, and her father who wouldn't change a dirty diaper, no less be an active parent. But the more Mary Shelley protested that her abhorrent creature should never have been born, the more she failed at her task, much like Milton's Satan.

While this is supposedly Victor Frankenstein's story, for the first time, a man-made being pled his case. The heart of the nested narrative is Shelley's biggest repudiation of her romantic and religious ideals, as the creature becomes his own protagonist, given most eloquent voice to demonstrate his plight and justify his violent acts, and like Satan in Paradise Lost, gives warning to future generations that the created might not take abandonment well.

Even though the creature was written to be the object of pity and fear, we cannot help but empathize with him and not with Victor, the protagonist and novel's namesake. The creature might have embodied the yucky fears of messing with God's works and human bodies, along with the uncertainty of the industrial and scientific revolutions, but equally, it released and blessed the future of medical technologies 
that created that monster - the very thing Shelley tried to criticize, all for the love of a child.

Frankenstein launched the gothic monster into the mainstream as the harbinger of modernity. During the same miserable week in a villa on Lake Geneva where a group of young people tried to scare each other and a young Shelley dreamt of her creature, Dr. John Polidori, their host's physician, created The Vampyre, the first literary popularization of the vampire myth that expanded the gothic subgenre. And vampires were definitely yucky... well, perhaps not for the men and women they seduced.

Regardless, many yuckier, monstrous characters appeared as the $19^{\text {th }}$ Century wore on, but we also observe a transition of protagonists from the creators (God, Prometheus, Rabbis, the Alchemists, and Victor Frankenstein) to the created. Once the protagonist is the monster, our empathetic relationship changes.

Inspired by the continuing industrial and scientific revolutions, the $19^{\text {th }}$ century birthed the monster as empathetic Protagonist, but they were still to be feared and pitied. And they don't end well. In Robert Louis Stevenson's Dr. Jekyll and Mr. Hyde, a man experiments on himself to be a hero, villain and ultimately victim. In HG Wells's The Sleeper Awakes, being the oldest and richest man in the world doesn't end well for the protagonist. He is the reason for war, revolution, betrayal and his own destruction. In Carlo Collodi's The Adventures of Pinocchio, the android puppet may want to be a real boy, but his all too human envy, stupidity, and greed kill him in the end. Spoiler alert: These three stories, and many more like them, end with the deaths of the protagonists, so the stories' morals remained: 'don't mess with creation.'

\section{The 20th century changes everything}

In 1900, a truly surprising work hit the mass audience. L. Frank Baum's The Wonderful Wizard of $\mathrm{Oz}$ was not only the story of a little Kansas girl's adventures in a fantasy land, but also about her fantastical sidekicks' desire for human prosthetics and uplift. Uplift is a science fiction concept named after David Brin's Uplift series, where a non-human animal or machine is made to have human or superhuman abilities. Other examples include HG Wells's The Island of Dr. Moreau, Planet of the Apes, as well as The Adventures of Pinocchio.

In The Wonderful Wizard of $\mathrm{Oz}$, three non-human friends of Dorothy each get to tell their story about how they desire parts them consider human to complete them. The Tin Man is the exemplar of this, having once been human, then cursed to chop off his limbs and replace them with tin prosthetics creating a cyborg. Then he chops up his torso and head, and crafts a fully tin android. But he still desires a human heart for what it represents. The guy's a lover, not a fighter, but he doesn't realize a real heart makes him no more loving than he already is.

The entire $O z$ mythic universe - which is a huge franchise of dozens of books, live theater, movies, TV shows, games, and more - is filled with wonderful examples of positive protagonists and sidekicks that are cyborgs, androids, uplifted animals and objects. My favorite is the transgender protagonist, Tip/Ozma, who turns out to be the real ruler of OZ. Baum explores the feelings and desires of these characters as valid and deserving as Dorothy, the Wizard or other humans from the real world. 
They don't pay an ethical price for their creation or their uniqueness. They get to be who they are or who they wish to become, and usually live happily ever after.

Unfortunately, in the 1920s and early 30s came the ethical backslide. The swings and roundabouts of economic and political fortunes accentuate the negative feelings we have for technology and people unlike ourselves. Fearful times bring fearful responses. We lost empathy. Our fears of capitalism, communism, fascism, Social Darwinism, racial and ethnic communities, industrialization, a global economic depression, and a past and future war, fueled a resurgence of Gothic monsters in the filmmakers of Germany with Metropolis, The Golem, Nosferatu, The Hands of Or$l a c$, and in the US at Universal Pictures with Frankenstein, Dracula, The Wolf Man, The Mummy and others.

The Universal Monsters were especially successful because the superhuman, monster and creator characters were more horrific and less empathetic. Rendered mute, Frankenstein's creature was stripped of his eloquence, even though the actor Boris Karloff tried his best to imbue his role with empathetic humanity. These stories reflected our fears and in turn, made us afraid.

\section{And heeeeere's Yummy!}

In 1933, at our darkest hour arose a great light: the superhero! The same year Hitler took power, two children of Jewish immigrants growing up in Cleveland, $\mathrm{OH}$ took Nietzsche's idea of the Übermensch and turned it on its head by creating Superman.

Übermensch means superman. Nazis perverted Nietzsche's philosophical idea into a master race bent on racial, religious and ethnic persecution. Created by Joe Shuster and Jerry Siegel, the US's first society-friendly "other," and positive superhuman hero helped create the Golden Age of comics. Superman single handedly changed the argument about monsters, superhumans and the "other".

This Moses-on-steroids fueled a one-superhero empathy engine. Like the religious allegory, the superbaby is sent in a rocket bassinet through space to new parents who adopt him into their foreign, American ways, not knowing the hero, leader and icon the superbaby will grow up to be. His Old Testament inspiration, Moses, is the United States's most potent allegorical character. The Puritans's mythic journey to the Promised Land of the New World was described in Exodus imagery. So, too, Manifest Destiny, immigration, the abolitionist movement, and civil rights. In addition, Superman was idealistic, moral, willing to be looked upon as pathetic, ridiculous and toil amongst mortals to protect his loved ones. And he's an immigrant adopter of middle-class American values. And he's tall-dark-and-handsome. He's the American ideal we were taught to aspire to. We wanted to be Superman, immigrant or native-born.

That was quite a change from fearing alien superhumans.

The Golden Age of comics also introduced human enhancement experiments like Captain America, morally determined technocrats like Batman, and of course, Wonder Woman, a superhuman kickass by being a demigod female without contact with men. But why this positive upsurge in speculative fiction protagonists in the 1930's and 40's? After a raft of monsters, imagined and real in the figures of Hitler, Mussolini, Emperor Hirohito and Stalin, Americans wanted a savior and the superhuman "others" were designed specifically to manage the job. 
From this point on, the status quo in speculative fiction was bucked and we ourselves were doing the bucking at an accelerated rate. As always, technology led the way. The line between yucky and yummy shifted tremendously in the $20^{\text {th }}$ Century as scientific advancements raced ahead and our "other" protagonists both followed technological trends, examining their ethics, and leading the way imagining new futures in a feedback loop of increasing empathy.

Here are a handful of technologies that inspired the creation of yummy speculative fiction protagonists and their stories, along with a few titles they inspired:

Discovery of DNA: More Than Human, Blood Music, X-Men, Teenage Mutant Ninja Turtles

Genetic engineering: Dune, Guardians of the Galaxy, Maximum Ride, Heroes, Ender's Game

Radiation's children: The Fly, The Incredible Hulk, Godzilla, The Incredible Shrinking Man, Spiderman

Birth control, the sexual revolution and STDs: Interview with a Vampire, Bram Stoker's Dracula (directed by Francis Ford Coppola), True Blood, Vampire Diaries

Cognitive augmentation and neuroscience: Flowers for Algernon/Charly, The Matrix, Total Recall, Dr. Xavier in X-Men, Limitless, (R)evolution

Robotics: R2-D2 and C-3PO in Star Wars, Data in Star Trek: The Next Generation, The Iron Giant, Robocop, Blade Runner, Chappie, (ID)entity

Space travelers: Stranger in a Strange Land, Star Trek, 2001: A Space Odyssey, David Bowie's Starman, Interstellar

Search for Extraterrestrial Life: The Day the Earth Stood Still, Starman, ET: The Extraterrestrial, Contact, Arrival

Organ transplants and prosthetics: The Six Million Dollar Man, The Bionic Woman, Ironman, Robocop

Reproductive Medicine: The Unborn, Alien 3, Gattaca, The Handmaid's Tale

The Computer revolution: The Matrix, Snow Crash, The Ghost in the Shell, The Moon is a Harsh Mistress

Longevity: Peter Pan, Highlander, Interview with a Vampire, Sleeper, Dr. Who

And finally, Leon Kass's great bugbear, cloning: Kiln People, Altered Carbon, The Prestige, Never Let Me Go

These stories reflect our cultural evolution and liberalization. There is a century-long feedback loop of technology and protagonists that inspire artists to examine new technologies or aspirations, and create new protagonists to play through the consequences of being that 'other.'

Monsters and superheroes are now so familiar, familiarity breeds humor. As seen in classics like The Munsters, Young Frankenstein and The Rocky Horror Picture Show, it's impossible for Frankenstein's creature to scare us now, especially when we can relate to his foibles, so can we laugh at him and with him. Point of view changes everything. As a child, Casper The Friendly Ghost was the friendliest ghost we knew, because he was the only ghost we knew. We related to him, his fears, his loves and his goals. Empathy grows as we discover we're more like the 'other' by virtue of our shared ethics than we are like those who try to defeat them.

But as Paradise Lost and Frankenstein warned us, what happens when we lose control of our creations? Do we need our own God-like omniscience to do an ade- 
quate job of supervising them? Will artificial intelligence be enough to convince us we're some kind of superman? 'Superman' is like 'yuck factor' - its relative only to the status quo of what "human" means, and what we've achieved at that moment in time. As the human species and society evolves, and our sense of disgust changes, the yuck factor moves away, an imaginary line to be pondered, teased and inevitably transgressed as it leaps out before us again.

So if the subjects of our previous disgust cease to be frightening because we have empathy for them, then it's time to throw out Kass's "wisdom of repugnance" on the trash heap of bogus philosophies where it belongs. The fear it represented can't stand up to the thousands of stories that have taken the "other" from reviled pariah to cultural hero. And that fear is no match for our compassion, no less the clarity of reason. As artist Francisco de Goya so beautifully illustrated, "The Sleep of Reason Produces Monsters," but so does the sleep of empathy.

\section{So why is this important?}

Cultural evolution comes from stories and technology. They go hand in hand. Right now, we're in a battle of stories, because of new social media technologies. Some call it weaponized narrative. Others call it memetic warfare or information warfare. In this battle, those who wish to create chaos and hate in society to gain the upper hand tell stories that kill empathy by squeezing the in-group, lessening the size and context for whom we should have empathy. Their stories make you think you're alone. They divide us from one another. They tell you that you should be afraid. That you have no choices. That you should shut up. Because when you're not in the story, you can be ignored.

We're in a historical period akin to the 1920s and 30s, but we've seen these stories of these behaviors before. In Huxley's Brave New World, Orwell's 1984, LeGuin's The Dispossessed, Collin's The Hunger Games trilogy, among so many others. Once again, oligarchs and demagogues are taking over nations, creating "monsters" and the "other". They lie and try to sell the propaganda as reality. Back in the 1920s-30s, there was no instant global communication media, so no one knew what was happening in real time. Most didn't have enough education to understand the historical precedent, and had no idea what to do, so often preferred to do nothing. For them, it was too big a problem.

But not now. Not for all of us. Many are aware. We know our history. And we know what we have to do.

Our present youth generation has been exposed to a host of stories where young people battle dystopias or despots and save the world or universe. In Black Panther, Harry Potter, The Ghost in the Shell, The Hunger Games, and once again in the Star Wars films, we see a larger context of who to have empathy for and who is a leader. It's not only important that you see yourselves in stories to feel empowered. It's important that others see you so they can grow their empathy and make your empowerment easier. There's a reason that stories like these have captured a generation's imagination. The stories speak a truth they understand. And speculative fiction allows us to tell the hard stories: hard to tell, hear, and accept.

Martin Luther King, Jr. paraphrased abolitionist minister Theodore Parker when he said, "The arc of the moral universe is long, but it bends towards justice". I see 
that arc as a story arc. One way to a constructive, inclusive, positive world that honors this vision is to tell lots of positive stories. As a speculative fiction author myself, I don't care what anyone ends up doing for a living. You don't need to tell stories professionally, although doing so brings more professional voices to the fight. Be seen. You matter. Tell our own stories and the stories of others. Tell both true and fictional stories. But most importantly, like the best storytellers, make these stories universal in their appeal. And make them from our hearts.

We must spread these stories as pervasively as possible, using as many forms of media as possible, in the hopes of catching those who don't understand, so when they read or see or VR that story, they might say to themselves, "You and I may not be alike, but now I think I understand you. And I think you'd understand me, too, if I told you my story".

And that's how yucky gets yummy. 